\title{
Exploration of the Necessity and Feasibility of University Library Opening to the Society
}

\author{
Jun $\mathrm{WU}^{1, \mathrm{a}}$, Shu-Lun $\mathrm{Al}^{2, \mathrm{~b}}$,Zhao-Quan $\mathrm{Al}^{3, \mathrm{c}, *}$ \\ ${ }^{1}$ Hubei University Library, Wuhan, China \\ ${ }^{2}$ College of Chemistry and Molecular Sciences, Wuhan, China \\ ${ }^{3}$ Wuhan University, Wuhan, China \\ a844327739@qq.com, ${ }^{\text {b}} 770570463 @ q q . c o m,{ }^{c}$ aiz-q@sohu.com
}

*Corresponding author

Keywords: University Library, Open to the Society, Necessity, Feasibility.

\begin{abstract}
In this paper, the necessity and feasibility of social openness are demonstrated and discussed in many aspects. We will explore dissertation by celebrities from ancient to modern times. In addition, university library opening to the Society is the requirements of the regulations of the Chinese government, is an important strategy to implement the strategy of rejuvenating the country through science and education, is an important symbol of the development level of national civilization, is a common practice in developed countries, is an important standard to measure innovation concept and management level of a library . It is pointed out that the university library, as the cradle of human civilization, is the inevitable trend of social development.

University libraries opening to the outside world is an old topic, which is discussed as early as in 1997 by the scholars from the library. After 20 years of continuous arguments, there are still many different opinions about it from all sectors of the community .So university library still has a strong resistance to open to society successfully. There is no doubt that knowledge is wealth and power and the best way to access to knowledge is to read. There are many and famous books for reading and borrowing in the library. However public Libraries in Our Country are too few. And the current situation of our country is that almost all hundreds of thousands of people have a library in many big cities. Now the total number of colleges and universities in the country is more than 1600 and there are several or even dozens of colleges and universities in each city.

So on the one hand many university library resources have not been fully utilized, on the other hand so many people in the society have no book to read. In this paper, the necessity and feasibility of social openness are demonstrated and discussed in many aspects. We will explore dissertation by celebrities from ancient to modern times. In addition, university library opening to the Society is the requirements of the regulations of the Chinese government, is an important strategy to implement the strategy of rejuvenating the country through science and education, is an important symbol of the development level of national civilization, is a common practice in developed countries, is an important standard to measure innovation concept and management level of a library . It is pointed out that the university library, as the cradle of human civilization, is the inevitable trend of social development.
\end{abstract}

\section{In China only if University Library is Open to the Society Indeed, Can We Be "Never too Old to Learn".}

17th-century German famous library scientist nords put forward: library should open not only for special class but also for all who are willing to come to the library to study. Lenin said once: to satisfy people's needs for reading, The government achieved a goal of finding a library every 10 to 15 minutes by walk; A standard from International Federation of library associations is that everyone at home as the center, can find a library by walking in 15 minutes to any direction to; Chinese premier Wen Jiabao said: " reading can give people the wisdom, make people brave, and let people warm. I would like to see people to read a book in his hand in the subway. Because I've 
always thought that knowledge could give a person power, security, and happiness "; Mao Zedong is a great man because he insisted in reading all his life; Ancient Athens famous politicians solon said, " Never too old to learn". The most important learning is reading. Because of China's large population and limited personal library, only if university library is open to the society indeed,can we be " Never too old to learn ".

\section{The library Opening to the Public Is an Important Symbol of the Development Level of National Civilization}

Chinese capital library curator Ni xiaoJian said: "a good cultural atmosphere has not been established, because of China's cultural positions continuously erosion, the abnormal development of cultural consumption now. The library should bear a responsibility for realizing own cultural infiltration and spreading culture to the surrounding. Citizens can have right to access to literature information and knowledge from the library fairly ${ }^{[1]}$.The idea of providing services from University library for teaching and scientific research is too backward, and not the international concept of the library. The library opening to the public is an important symbol of the development level of national civilization. The university library must help everyone from the city concept of reading, let citizens to share the joy of reading, let people to acquire knowledge and information from the library to create wealth for the society and the individual.

According to statistics, book circulation rate of university library in China on average is less than $46 \%$, even the individual is also less than $25 \%$--In other words there are lots of books in the bed" by $2014^{[2-3]}$. Especially during the summer and winter vacations, many people crouch or stand, and even sit on the floor to read with pleasure. So on the one hand many university library resources have not been fully utilized, on the other hand so many book lovers in the society have no book to read. University library should open the door to them as soon as possible. Luo Min from the library of Jiangsu University think that only to break the shackles of resources for the promotion of social services, discipline development will be promoted ${ }^{[4]}$.

\section{University library Opening to the Whole Society is the Common Practices in Developed Countries}

From the experience of foreign countries, the vast majority of college libraries in western developed countries are open to the public which can get access to information from the library.

About $10 \%$ of the readers in university library is ordinary citizens. In the Nordic countries, some of the university library facing the social public have a double identity of university library and public libraries. All of public university libraries in the United States [4-5] are open to the public which don't need any identification. Yale university library even has become a "scenic spot" for visitors. When people enter it and see the students diligently, they will inevitably be affected and have to sit down with reading impulse and read together. Although some private universities are not open to the public, but in practice they cannot strictly refuse outsiders into. The Harvard University is a private school [6] and in principle, only teachers and students can get in, but the people getting in it will not be rejected. The ratio of university library open to society in Japan in 2001 is $98 \%$ [7-8].

\section{The University Library to Open to the Public is Stipulated in Chinese Regulations}

In 2002 China's ministry of education issued the "regulations of common colleges and universities library", which stipulated that "conditional higher school library should open to society and community readers" as far as possible. The national "11th five-year plan" period cultural development plan outline proposed: "the cultural facilities of organs, enterprises and schools is open to the public, as far as possible, and these institutions actively develop cultural services."Library is a symbol of cultural knowledge and is the cradle of human civilization. The advanced degree, popularity and service level of Library is a symbol of national civilization. If only for their service 
in colleges and universities, it is in the edge of the culture.

\section{There Have Been Some Successful Examples of University Library to Open the Society}

"University library opening to the society" has been put forward in China for more than ten years. Now only the university libraries in some developed coastal areas break the boundaries of University Libraries and public libraries and open to the public for free such as Hainan University library, Xiamen University library and Ningbo University Park library and so on; Many university libraries in Beijing and Shanghai cities are also opening to the society, such as Tsinghua University, Nanjing University, Wuhan University and other minority university libraries in which you can do temporary card for learning in the library, and reading in the part of the reading room every day, but the charge is 2 yuan per day. The provisions of Beijing Normal University library and Tsinghua University library are similar.

Fudan University library provides temporary library card valid for external readers with the relevant guarantee and letter of introduction for one year, but you must pay an annual fee of 100 yuan depreciation books. external readers can obtian certain reading services in Library of Renmin University of China" ${ }^{[9]}$. The library regulations stipulated that external readers shall pay the service fees according to the standard to find a book or a database, and can borrow books for reading and copying only in the library. In addition, the books may not be taken out of the library.

\section{The Degree of Library Opening to the Public Is An Important Standard to Measure Innovation Concept of A Library}

University libraries opening to the outside world will be inestimable influence to the improvement of quality of universal, and be the obligatory responsibility because of university library as a part of the public cultural resources. In fact, the degree of library Opening to the public is an important standard to measure innovation concept and management level of a library.

In our country, millions of graduates get into all walks of life every year. Not every enterprise can be able to haye extensive electronic resources like school library. So it is difficult for these workers encountering problems in the work to consult the data, or need to self-study. Limited number of public library, wide collection types and master of none etc, have brought inconvenience to residents. Compared to the social library, The university library books have many incomparable advantages and cutting-edge frontier. Huang Zongzhong [10] proposed library to continuous innovation, to share the library literature resources with the whole society. Not only for the development of the society to contribute but also out of obligation, the university library should open the door to meet the most basic needs of clients. By the culture infiltration and spreading to the surrounding, citizens appreciate and know university teaching and research atmosphere in the near distance, and consciously accept the influence of various cultural knowledge to improve their own quality. It can make full use of social resources, be convenient for public learning, strengthen the special education function of university library, create a rich cultural atmosphere of the community, optimize the social atmosphere and promote community harmony.

\section{The Library Opening to the Public is An Important Strategy to Implement the Strategy of Rejuvenating The Country Through Science and Education.}

Education is important basic national policies in our country. There is no doubt that a developed country must never be based on low science culture quality for public. Only if each citizen adheres to the "lifelong learning" and constantly improve the quality of recuperation, society will progress and the nation can revive. University library opening to society plays the positive role without a doubt. In addition to its effective utilization of literature resources of university library to serve the society and realize national benefit, but also it can reflects the social responsibility of University library. Any reasons for refusing to open university library to the public are pale. University libraries should change the traditional ideas, reveal the essential attribute of library, open the door to 
the ivory tower, open to all who are willing to come to the library to study. Make university library become no "library of the fence." Make China's university into a real "no walls university". Make Chinese community eventually transformed into community without walls. At the same time it can let the students in the ivory tower contact with the public midly. This allows lasy college students with learning pressure and power, so that they can recognize the fierce competition increasingly, and there is a psychological preparation before entering the society.

\section{The Degree of Library Opening to the Public is an Important Standard to Measure Management Level of a Library}

Some people think that these phenomena are good beginning of university library opening to the public, however, some people questioned the reasonability about setting these open "restrictions" for the university library. An expert from Information management department of Beijing university said that the countries have been actually encouraging university libraries opening to the outside world and Directors of University Libraries will not explicitly resist to open and cannot solve this problem, because university library opening to the public is a complex problem. First university library staff is set based on the number and needs of the readers. If opening to the outside world, the managers is not enough; Secondly, resources are targeted and more professional books are used for teaching and scientific research for students and teachers from the content of the library collection of books. In recent years, because of a number of college expansive enrollment, some colleges and universities library itself is overcrowded and the security to borrow for the teachers and students is a problem, so the open can't be implemented in the short term. In addition to fully open to public, it will involves a large number of funds and facilities construction costs. There is still great resistance for University library to open to society.

In addition, 5\% of readers think it doesn't matter that whether the university library open to the public or not, $11 \%$ of readers consider that it is limited for University library to open to society. Some opponents argue that the university library open to society will have many adverse effects on self-study and borrowing for the students in the library[5]. For example, an influx of migrants will make the library crowded and noisy and broke the quiet campus. In addition the influx of a large number of social readers, the space of our school students will undoubtedly been occupied, and the workload of the library staff will increase. Some people complain that books were borrowed to people outside the school, so students can have no books to borrow. people are afraid that the quality of migrant workers uneven in quality will have adverse effects on university ethos. Xu Yingzhe[11] analyzed the case of technology innovation service society of the American library. they not only opened the library to the public free, but also developed fast query site for library self-service online, and simultaneously launched the APP mobile wireless Internet mobile phone system. People in the United States can search every library all documents online by scaning two-dimensional code in many public places[12,13] such as Stanford university library. So the degree of library Opening to the public is an important standard to measure management level of a library.

\section{University Library Has a Lot of Free Time to Open to the Public Readers}

Firstly, according to our many years of observation, because most students have lessons in the morning, or in the morning reading. So each big university libraries are generally very empty in Monday through Friday morning each week, and the occupancy rate is less than $20 \%$. In general Students is slowly increased at 10 a.m, but the occupancy rate is not more than $60 \%$.Secondly, $98 \%$ students will return to dormitory to have a rest at 12 am to 2:00 in the afternoon every day, but the librarian is working normally; Third, the library and the reading room occupancy rate are below $80 \%$ every day in the afternoon to the evening, except that the library is very nervous and almost filled up during three to four weeks before the final exam. Fourth, most of the students go home or visit relatives and friends and not go to the library in the holidays or at weekends especially for nearly three months of summer and winter vacations. It is a good opportunity for university library 
to open to society during these time.

\section{Many Remaining Book Information Data from the University Library Can Be Open to the Public Readers}

On the one hand, we analyze based on decades of experience to work in the library, that college students are mostly borrowed some of the latest professional books and problem sets, rather than cutting-edge and too basic books. Only a few students occasionally borrow some novels classics, newspapers and magazines to keep track of current events. On the contrary social readers especially senior intellectuals need to borrow some professional books generally, and most of older readers like a fiction books or utility class information and library collection of old newspapers and magazines. On the other hand, it is difficult for professional people outside to enter the forefront of a subject, so the school part-time academic enthusiasts is less likely to borrow those advanced books, namely external borrowing generally does not affect the teaching and scientific research of university teachers and students. In the end, A kind of utility system design is very difficult to implement under the attention to input and output of capital logic. But if manageing the Library actively, there are still possible. If Library is partitionsed, such as professional areas and opening areas to the outside, not only the intellectual resources of the university can be fully utilized, but also the visibility of schools and libraries can be improved and the socialization of university library can be realized. The university and the society will be a win-win thing.

\section{Don't Worry that Migrant Workers Have Adverse Effects on College Students}

Of course, taxpayers providing University education funding have the right to enjoy our fair share of public resources. The essence of University library opening to the public is to develop more readers and display collection to the public to a maximum degree. Now for idle books resources of university library, why can't we use better? And those who want to go to the library borrowing books are generally senior intellectuals, thirst for knowledge of studious, want to go further in their field, or want to read to enrich my life. So the quality of these people will be not lower.

Some people say that the nature of the colleges and universities are facing the whole country. So Why can even around ordinary people not be tolerant? Others people say that college is a place of education, so why can the library not for ordinary citizens to provide a learning environment and space? Some people think that colleges and universities is enclosed in order to protect the students and don't let them contact with social idle personnel, but people going to the library to study have the high quality rather than a disaster. For example Mao Zedong as a social readers came to the Peking University library for reading a large number of books and materials about communism, so that he made Chinese revolution success.

\section{References}

[1] Valerie A. Harris, Ann C. Weller. Use of Special Collections as an Opportunity for Outreach in the Academic Library [J]. Journal of Library Administration, 2012, 52(3):294-303.

[2] Wei Jianlin. The Confusion and Reflection of University Library's Opening to the Society [J]. Library Development, 2013(1):85-89.

[3] Li Chunning. The Discussion about University Library of Opening to the Society in the New Period[J]. Information Research, 2012(11):123-125.

[4] Liu Zihui. The Research of University Library Opening to the Society [J]. Library Development, 2013(4):56-59.

[5] Johnson S P, Menor L J, Roth A V, et al. A Critical Evaluation ofthe New Service Development Process[J]. Integrating Service Innovation and Service Design, 2000, 1-16. 
[6] Connaway L S, Alexander S, Lewis J S, et al. 2012 Top Ten Trends in Academic Libraries: A Review of the Trends and Issues Affecting Academic Libraries in Higher Education[J]. College \& Research Libraries News, 2012, 73(6):311-320.

[7] Tenopir C, Sandusky R J, Allard S, et al. Research Data Management Services in Academic Research Libraries and Perceptions of Libraries [J]. Library \& Information Science Research, 2014, 36(2): 84-90.

[8] ACRL Research Planning and Review Committee. Top Trends in Academic Libraries: A Review of the Trends and Issues Affecting Academic Libraries in Higher Education[J]. College \& Research Libraries News, 2014, 7(6): 294-302.

[9] LiuMin. Some Ideas About the Innovation of Management Mechanism in Universities Library[J]. Library, 2011, 5: 126-127.

[10] Huang Zongzhong. Theory of Library Innovation[J]. Archival Science Books, 2016, 30 (6): $1-4$.

[11] Xu Yingzhe. The Innovation Service and Enlightenment in America Library-the United States in 2014 Case Library New Technol ogy Application[J]. Library Science Research, 2015, 4, 95-100.

[12] Liu Qifei. The Analysis and Enlightenment about Innovation Prize of Stanford University Research Library[J]. Library Science Research , 2014, 19, 90-92.

[13] Liu Yang, Ni Guo. France's National Digital Library Construction and the Development of Digital Library of Our Country's Enlightenment[J]. Journal of Book Intelligence Knowledge, 2013, 2, 119-124. 